\title{
PENGELOLAAN SDA DAN HAK-HAK MASYARAKAT ADAT: STUDI KASUS ENGGANO'
}

\section{NATURAL RESOURCES MANAGEMENT AND ADAT COMMUNITY RIGHTS: ENGGANO CASE STUDY}

\author{
Laely Nurhidayah \\ Pusat Penelitian Kemasyarakatan dan Kebudayaan \\ Lembaga Ilmu Pengetahuan Indonesia \\ lae_ly@yahoo.com
}

\begin{abstract}
Enggano adat community is one of adat community who is still struggling to fight for their customary right including the right of adat forest. Consitutional Court Decision No 35/PUU/2012 is a landmark decision for the recognition of adat forest in Indonesia. Study found that Enggano adat community has the elements to fulfil requirements as adat community or adat village. These include: They have adat community, adat territory and adat customary law which is obeyed by the community. This paper concluded that local government need to recognize their existence as adat community. This recognition is important so they can claim for their their ulayat right and conserve the Enggano island from exploitation to the natural resources from people outside adat community.
\end{abstract}

Keywords: land and forest natural resources management, adat community, adat village, local government law, ulayat right.

\begin{abstract}
Abstrak
Masyarakat adat Enggano adalah masyarakat yang sedang memperjuangkan hak adatnya dalam pengelolaan sumber daya alam termasuk hutan adatnya. Keputusan MK No 35/PUU/2012 merupakan landasan hukum bagi pengakuan hak-hak masyarakat adat termasuk hutan adat. Berdasarkan hasil penelitian masyarakat Enggano memiliki elemen-elemen dasar untuk dapat memenuhi syarat untuk diakui hak adatnya oleh pemerintah, bahkan memenuhi syarat untuk pembentukan desa adat seperti ada masyarakat adat yang mendiami wilayah tertentu di Enggano serta memiliki peraturan-peraturan adat yang ditaati dan dilaksanakan dalam kelompok adatnya. Artikel ini menyimpulkan bahwa pemerintah daerah Bengkulu perlu melindungi hak-hak adat masyarakat adatnya dalam peraturan daerah. Pengakuan ini sangat penting dalam rangka menjaga lingkungan dan sumber daya alam Enggano dari eksplotasi dari pihak di luar adat Enggano.
\end{abstract}

Kata kunci: pengelolaan SDA hutan dan laut, masyarakat adat, desa adat, peraturan daerah, hak ulayat.

\section{Pengantar ${ }^{1}$}

Masyarakat adat Enggano merupakan salah satu masyarakat adat yang sedang memperjuangkan pengakuan dan perlindungan hak-hak adatnya terutama wilayah adat. Selama ini hak masyarakat hukum adat banyak terabaikan, terutama hak-hak atas pengelolaan sumber daya alam, termasuk hutan dan laut. Faktanya, sering kali terjadi konflik antara

${ }^{1}$ Artikel ini merupakan hasil penelitian lapangan EWIN 2015 Enggano dan pengembangan laporan DIPA Enggano 2016. kesatuan masyarakat hukum adat tersebut dengan perusahaan yang memanfaatkan hutan adat mereka. Konflik seperti ini merupakan permasalahan umum yang terjadi di seluruh Indonesia. Hal ini lahir karena beberapa hal. Misalnya, pengaturan dalam UU No. 41/1999 tentang Kehutanan yang menyebutkan bahwa seluruh hutan di wilayah Indonesia dikuasai oleh negara dan menyatukan hutan adat ke dalam hutan negara. Kemudian, masih banyak wilayah adat dan hutan adat yang belum diakui oleh pemerintah. 
Terabaikannya hak adat dan konflik atas lahan ini terjadi juga di Enggano. Persoalan bermula dari rencana pembukaan lahan oleh PT. Enggano Dwipa Persada (EDP) di pulau seluas $460 \mathrm{~km}$ (46.000 ha) untuk usaha pakan ternak yang kemudian berubah menjadi perkebunan melinjo. PT. EDP mengajukan dua surat permohonan pelepasan status hutan ke Departemen Kehutanan, pada tanggal 26 September 1991 dan Februari. Dalam suratnya, PT. EDP memohon pembebasan lahan 10.000 ha, lebih dari $20 \%$ luas pulau, untuk usaha pakan ternaknya (GATRA, 1995). Permohonan itu sebenarnya ditolak oleh Menteri Kehutanan dengan dasar bahwa Enggano merupakan kawasan pulau yang dicadangkan untuk fungsi hutan lindung serta hutan produksi terbatas. Namun, dengan bermodalkan surat izin prinsip dari Gubernur Bengkulu yang dikeluarkan pada tahun 1991, perusahaan ini mulai mendaratkan alat-alat berat ke hutan Enggano.

Pembukaan hutan ini menimbul prokontra di masyarakat. Lima kepala suku Enggano mengirim surat kepada Menteri Kehutanan, Menteri Lingkungan Hidup, dan Menteri Dalam Negeri, untuk meminta penebangan hutan oleh PT. EDP dilarang dan dihentikan. Lokasi pembukaan lahan 600 ha ini berada di wilayah Desa Banjar Sari dan memanjang melintasi enam desa, yaitu Desa Banjar Sari, Meok, Apoho, Malakoni, Kaana, dan Kahyapu yang akan dikonversi menjadi perkebunan kelapa sawit (WALHI, 2014). Hingga saat ini, penyelesaian kasus pembukaan lahan bekas PT. EDP ini masih belum jelas. Penyerahan tanah adat (bekas PT. EDP) seluas 2.400 ha melalui Surat Gubernur tentang hutan kemasyarakatan pun menjadi tidak efektif karena Kepala Desa merasa berhak mengatur tanah tersebut.

Beberapa persoalan yang terjadi di Enggano telah memicu gerakan dan tuntutan pengakuan hak masyarakat adat. Pertama, persoalan eksploitasi sumber daya alam oleh pihak dari luar Enggano serta konflik antara masyarakat adat Enggano dengan perusahaan. Kedua, persoalan semakin banyaknya tanah adat yang telah dijual kepada orang lain atau pendatang. Hal ini berdampak pada keberadaaan hak tanah adat di Enggano yang semakin terkikis. Ketiga, kasus pelaporan dugaan penjualan tanah ulayat oleh oknum aparat desa yang dilaporkan oleh para kepala suku ke pihak kepolisian. Keempat, terjadinya dualisme kepemimpinan di Enggano, yaitu antara kepemimpinan adat dengan kepimpinan desa. Pihak Adat beranggapan bahwa kelembagaan adat sama sekali tidak dilibatkan dalam pengeluaran Surat Keterangan Tanah (SKT) oleh Kades. Padahal secara Adat, Kepala Desa (Kades) dianggap tidak berhak mengeluarkan surat/keputusan apapun atas tanah adat. Secara umum, dari perspektif kepala adat, tanah di Pulau Enggano adalah tanah adat (inyah panapue) yang dimiliki secara turun temurun berdasarkan aturan adat Enggano dengan pembagian wilayah berdasarkan wilayah adat suku (kaudar). Akan tetapi, di sisi lain, pihak desa juga berangggapan bahwa kepala suku tidak berhak ikut campur tangan dalam pengeluaran SKT. Kelima, konflik pengelolaan sumber daya yang kian bertambah. Baru-baru ini terdapat pelaporan kasus dugaan penambangan pasir pantai yang dianggap illegal di Desa Kaana, Kecamatan Enggano, Bengkulu Utara yang diduga dilakukan oleh perusahaan pembangunan daerah transmigrasi di Pulau Enggano.

Perjuangan pengakuan hak masyarakat adat di Indonesia memang sudah berlangsung cukup lama. Sebagai satu negara kepulauan yang berpenduduk sekitar 230 juta orang dan terdiri dari lebih 700 etnik dan subetnik, sekitar 50-70 juta penduduk Indonesia termasuk ke dalam kelompok masyarakat pribumi/adat (BP REDD, 2017). AMAN dalam Draft RUU Pengakuan dan Perlindungan Hak Masyarakat Hukum Adat menyebutkan bahwa masyarakat adat telah banyak mengalami ketidakadilan, pemaksaan nilai-nilai spiritualitas dan budaya, pemaksaan pembangunan yang tidak sesuai dengan kebutuhan masyarakat adat, pengambilalihan hak atas tanah, wilayah, dan sumber daya alam, sehingga menghalangi mereka untuk berdaulat, mandiri dan bermartabat sebagai bagian dari bangsa Indonesia.

Draft RUU Pengakuan dan Perlindungan Hak Masyarakat Adat juga menyebutkan bahwa Masyarakat Hukum Adat selama ini belum diakui dan dilindungi secara optimal dalam melaksanakan hak pengelolaan yang bersifat komunal, baik hak atas tanah, wilayah, budaya, dan sumber daya alam yang diperoleh secara turun-temurun, maupun yang diperoleh melalui mekanisme lain yang sah menurut hukum adat setempat. Pada kenyataannya memang banyak konflik perebutan hak atas tanah antara masyarakat adat dan pengusaha dalam pembukaan lahan untuk konsensi perkebunan. 
Hal ini disebabkan kepemilikan tanah adat di dalam perundang-undangan sangat lemah.

Pada tingkat internasional, pengakuan hak masyarakat adat sudah dilakukan. Hal itu seperti tertuang dalam Konvensi ILO No. 169 tahun 1989 tentang Hak Masyarakat Adat dan Suku-Suku di Negara Merdeka dan Deklarasi PBB tentang Hak-Hak Masyarakat Adat tahun 2007. The United Nations Declaration on the Right of Indigenous People (UNDRIP) menyebutkan bahwa ada kebutuhan mendesak untuk menghormati dan mempromosikan hakhak masyarakat adat, terutama hak atas tanah, kawasan, dan sumber daya alam. UNDRIP merupakan penegasan hak-hak kolektif masyarakat adat, termasuk hak-hak masyarakat adat untuk menentukan nasib sendiri, persetujuan bebas tanpa paksaan, didahulukan dan diinformasikan atau FPIC, hukum adat, hak atas tanah dan sumber daya alam, hak-hak budaya, dan hak-hak yang lainnya.

Meskipun Indonesia belum meratifikasi konvesi ILO yang berkaitan dengan masyarakat adat dan pribumi, hak-hak masyarakat hukum adat di Indonesia telah diakui dalam UUD 1945 dan dalam peraturan perundang-undangan lainnya. Negara telah memberikan pengakuan, penghormatan, dan perlindungan terhadap masyarakat hukum adat melalui sejumlah aturan. Beberapa peraturan itu diantaranya UUD 1945, UU No. 39/1999 tentang Hak Asasi Manusia, UU No. 41/1999 tentang Kehutanan, UU No. 24/2003 tentang Mahkamah Konstitusi, UU No. 31/2004 jo UU No. 45/2009 tentang Perikanan, UU No. 7/2004 Tentang Sumber Daya Air, UU No. 27/2007 Tentang Pengelolaan Pesisir dan Pulau-Pulau Kecil, UU No. 32/2009 tentang Perlindungan dan Pengelolaan Lingkungan Hidup, Putusan MK No. 35/ 2012, serta UU No. 6/2014 tentang Desa.

Perundang-undangan seperti UU No. 41/1999 tentang Kehutanan telah mendelegasikan kewenangan untuk pengakuan hak masyarakat hukum adat kepada pemerintah daerah. Hak masyarakat hukum adat yang perlu menjadi perhatian dalam peraturan daerah ini terutama adalah hak atas tanah dan kekayaan alam, meliputi hak ulayat dan hak perorangan para warga masyarakat hukum adat yang bersangkutan.

Belum adanya pengakuan hak adat masyarakat Enggano oleh pemerintah daerah menjadi persoalan yang muncul di tingkat bawah. Kekhawatiran masyarakat adat Enggano saat ini adalah adanya eksploitasi sumber daya alam Enggano yang dianggap mengancam kelestarian pulau terdepan di Samudera Hindia itu, seperti pembalakan liar dan penambangan pasir pantai. Belum adanya peraturan daerah yang menguatkan kepemilikan masyarakat adat tentang hutan adat dan ulayat tanah adat menyebabkan masyarakat adat tidak bisa mengontrol eksploitasi sumber daya alam.

Hal lain yang menjadi kekhawatiran adalah adanya ekploitasi wilayah laut sekitar Enggano. Sebenarnya masyarakat adat asli Pulau Enggano merasa dapat mengusir kapal-kapal asing tersebut karena selama ini masyarakat memiliki hukum adat yang menetapkan batasan sejauh 3 mil tertentu ke tengah laut, yang diperbolehkan bagi kegiatan penangkapan ikan. Hanya sayangnya, aturan adat tersebut belum dikukuhkan dalam bentuk aturan hukum seperti perda adat atau sejenisnya (Tasril, 2014). Perda masyarakat adat juga sangat diperlukan bagi masyarakat adat Enggano dalam hal fungsi perlindungan pulau mengingat tingkat kerentanan pulau yang berukuran $45 \mathrm{~km}^{2}$ itu cukup tinggi.

Artikel ini bertujuan mengidentifikasi persyaratan hukum yang diperlukan masyarakat adat Enggano untuk mendapat pengakuan hak adat dan hak ulayatnya dalam pengelolaan sumber daya alam serta opsi-opsi hukum yang dapat diambil untuk pengakuan adat Enggano berdasarkan peraturan perundang-undangan yang ada. Beberapa aspek yang menjadi persyaratan untuk diakuinya hak ulayat adat dan/atau pembentukan desa adat yaitu adanya masyarakat paguyuban adat dan wilayah, perangkat norma hukum adat, pranata lembaga adat, dan harta kekayaan adat. Sebelum melihat posisi dan opsi pengakuaan hak-hak masyarakat Enggano, terlebih dahulu artikel ini akan membahas dinamika perkembangan pengakuan hak masyarakat adat dalam hukum positif Indonesia sebagai bahan acuan kerangka dan landasan hukum bagi pengakuan hak masyarakat adat dan hukum adat di Enggano.

\section{Pengakuan Hak Masyarakat Adat dalam Perundang-Undangan di Indonesia}

Saat ini telah terjadi pergeseran paradigma mengenai pengakuan hak-hak masyarakat adat. Sejak reformasi bergulir tahun 1998, sudah banyak peraturan perundang- 
undangan yang lahir untuk mengakui keberadaan dan menguatkan hak-hak masyarakat adat atas tanah, sumber daya alam, dan hak-hak dasar lainnya. Berbagai produk legislasi tersebut menyentuh semua level, mulai dari konstitusi sampai peraturan desa. UUD 1945 Pasal 18 b Ayat (2) menyatakan bahwa negara mengakui dan menghormati kesatuan-kesatuan masyarakat hukum beserta hak-hak tradisionalnya sepanjang masih hidup dan sesuai dengan perkembangan masyarakat dan prinsip Negara Kesatuan RI. Akan tetapi, hambatan yang terjadi adalah belum banyak pemerintah daerah yang mengakui hakhak masyarakat adat dalam peraturan daerahnya, padahal syarat pengakuan masyarakat adat di berbagai peraturanperundang-undangan adalah adanya pengakuan masyarakat adat tersebut di dalam perda. Diakui dalam RPJMN bahwa tingkat penyelesaian kasus pertanahan dan penetapan batas tanah adat/ulayat masih rendah (hingga saat ini baru satu tanah adat/ulayat yang ditetapkan, yaitu Tanah Adat Baduy di Provinsi Banten).

Pemerintah telah mengakui kepemilikan hak ulayat masyarakat adat dalam beberapa peraturan perundang-undangan, antara lain UU Pengelolaan Agraria (UUPA) No 5/1960, UU UU No. 41/1999 tentang Kehutanan, UU No. 27/2007 tentang Pengelolaan Pesisir dan PulauPulau Kecil, Peraturan Menteri Agraria No. 5/1999 tentang Pedoman Penyelesaian Masalah Hak Ulayat Masyarakat Adat yang dicabut dengan Peraturan Menteri Agraria dan Tata Ruang No. 9 tahun 2015 tentang Tata Cara Penetapan Hak Komunal Atas Tanah Masyarakat Hukum Adat dan Masyarakat yang Berada dalam Kawasan Tertentu, Permendagri No. 52 Tahun 2014 tentang Pedoman Pengakuan dan Perlindungan Masyarakat Hukum Adat, Permen LHK No. P.32/Menlhk Setjen/2015 tentang Hutan Hak, UU No. 39 Tahun 2014 tentang Perkebunan, UU No. 6 Tahun 2014 tentang Desa, serta Peraturan Bersama Menteri Dalam Negeri Republik Indonesia, Menteri Kehutanan Republik Indonesia, Menteri Pekerjaan Umum Republik Indonesia, Dan Kepala Badan Pertanahan Nasional Republik Indonesia No. 79 Tahun 2014, No. Pb.3/Menhut-11/2014, No. 17/Prt/M/2014, No. 8/Skb/X/2014 tentang Tata Cara Penyelesaian Penguasaan Tanah yang Berada dalam Kawasan Hutan.

UUPA No. 5/1960 menyebutkan adanya kepemilikan hak adat tetapi masih lemah karena kepentingan nasional dan negara kedudukannya lebih tinggi dari hak adat. Pasal 2 Ayat (4) menyebutkan negara memiliki hak menguasai atas tanah yang dalam pelaksanaanya dapat dikuasakan kepada daerah-daerah swatantra dan masyarakat-masyarakat hukum adat. Pelaksanaan hak ulayat dari masyarakat hukum adat sepanjang menurut kenyataannya masih ada harus dijalankan sedemikian rupa sehingga sesuai dengan kepentingan nasional dan negara, yang berdasarkan atas persatuan bangsa serta tidak boleh bertentangan dengan undang-undang dan peraturan-peraturan lain yang lebih tinggi (pasal 3 UUPA).

Pasal 5 UUPA mengakui bahwa yang berlaku atas bumi, air, dan ruang angkasa ialah hukum adat, sepanjang tidak bertentangan dengan kepentingan nasional dan negara, yang berdasarkan atas persatuan bangsa, dengan sosialisme Indonesia serta dengan peraturanperaturan yang tercantum dalam undang undang ini dan dengan peraturan perundang-undangan lainnya, serta segala sesuatunya harus dengan mengindahkan unsur-unsur yang bersandar pada hukum agama.

UU No. 41 tahun 1999 tentang Kehutanan mengatur mengenai hutan adat. Ketentuan Pasal 1 Angka 6 berbunyi "Hutan adat adalah hutan negara yang berada dalam wilayah masyarakat hukum adat". Pasal 4 ayat (3) berbunyi "Penguasaan hutan oleh negara tetap memperhatikan hak masyarakat hukum adat, sepanjang kenyataannya masih ada dan diakui keberadaannya, serta tidak bertentangan dengan kepentingan nasional". Pasal 67 ayat (1) berbunyi "Masyarakat hukum adat sepanjang menurut kenyataannya masih ada dan diakui keberadaannya berhak: (a) Melakukan pemungutan hasil hutan untuk pemenuhan kebutuhan hidup sehari-hari masyarakat adat yang bersangkutan; (b) Melakukan kegiatan pengelolaan hutan berdasarkan hukum adat yang berlaku dan tidak bertentangan dengan undang-undang; dan (c) Mendapatkan pemberdayaan dalam rangka meningkatkan kesejahteraannya. Sementara itu, ayat (2) berbunyi "Pengukuhan keberadaan dan hapusnya masyarakat hukum adat sebagaimana dimaksud pada ayat (1) ditetapkan dengan Peraturan Daerah".

Kepemilikan hutan adat ini diperkuat dengan Keputusan Mahkamah Konstitusi No. MK 35/PUU-X/2012 tentang Hutan Adat. Keputusan Mahkamah Konstitusi ini merupakan suatu terobosan dan koreksi mendasar terhadap 
konsep dan praktik penguasaan tanah di Indonesia (Safitri dan Uliyah, 2014). Keputusan tersebut yang menetapkan menghapus kata 'Negara' dalam UU No. 41/1999 Pasal 1 Angka 6 sehingga Pasal 1 angka 6 UU Kehutanan menajdi berbunyi "Hutan adat adalah hutan yang berada dalam wilayah masyarakat hukum adat". Untuk melaksanakan Putusan MK tersebut, terbit beberapa Surat Edaran (SE) dan Peraturan Menteri. Surat Edaran Menteri Kehutanan No. SE.1/Menhut-II/2013 tentang Putusan Mahkamah Konstitusi No. 35/PUU-X/2012 tanggal 16 Mei 2013 yang ditujukan kepada Gubernur, Bupati/Walikota, dan Kepala Dinas Kehutanan seluruh Indonesia menegaskan bahwa penetapan kawasan hutan adat tetap berada pada Menteri Kehutanan. Surat Edaran tersebut mensyaratkan Peraturan Daerah untuk penetapan kawasan hutan adat oleh Menteri Kehutanan.

Berdasarkan peraturan-Peraturan di atas Pemerintah Daerah menjadi ujung tombak penting dalam pengakuan hukum adat. Pemerintah daerah seharusnya telah melakukan identifikasi wilayah adat di masing-masing wilayahnya seperti diatur dalam Permendagri No. 52 Tahun 2014 tentang Pedoman Pengakuan dan Perlindungan Masyarakat Hukum Adat yang menugaskan Pemda melakukan identifikasi masyarakat adat dan wilayahnya. Pengakuan dan perlindungan hukum adat dilakukan melalui tahapan:

(1) Identifikasi Masyarakat Hukum Adat;

(2) Verifikasi dan validasi Masyarakat Hukum Adat; dan

(3) Penetapan Masyarakat Hukum Adat.

Bupati/Walikota melalui Camat atau sebutan lain melakukan identifikasi dengan melibatkan masyarakat hukum adat atau kelompok masyarakat. Identifikasi dilakukan dengan mencermati: (a) Sejarah Masyarakat Hukum Adat; (b) Wilayah Adat; (c) Hukum Adat; (d) Harta kekayaan dan/atau benda-benda adat; dan (e) Kelembagaan/sistem pemerintahan adat. Berdasarkan hasil identifikasi tersebut kemudian dilakukan verifikasi dan validasi oleh Panitia Masyarakat Hukum Adat kabupaten/kota. Hasil verifikasi dan validasi itu diumumkan kepada Masyarakat Hukum Adat setempat dalam waktu 1 (satu) bulan. Panitia Masyarakat Hukum Adat Kabupaten/Kota menyampaikan rekomendasi kepada Bupati/Walikota berdasarkan hasil verifikasi dan validasi. Bupati/Walikota melakukan penetapan pengakuan dan perlindungan masyarakat hukum adat berdasarkan rekomendasi Panitia Masyarakat Hukum Adat dengan Keputusan Kepala Daerah. Jika masyarakat hukum adat berada di 2 (dua) atau lebih Kabupaten/Kota, pengakuan dan perlindungan masyarakat hukum adat ditetapkan dengan Keputusan Bersama Kepala Daerah

Peraturan Menteri Kehutanan No. P.62/Menhut/2013 tentang Perubahan Atas Peraturan Menteri Kehutanan No. P.44/MenhutII/2012 tentang Pengukuhan Kawasan Hutan. Namun, peraturan ini sepertinya bertentangan dengan keputusan MK. Pasal 24 A (1) PerMenhut No. P.62 menyebutkan bahwa keberadaan masyarakat hukum adat ditetapkan dengan Peraturan Daerah Provinsi atau Kabupaten/Kota. Peraturan Daerah memuat letak dan batas wilayah masyarakat hukum adat yang dinyatakan secara jelas dalam peta wilayah masyarakat hukum adat. Jika sebagian atau seluruh wilayah masyarakat hukum adat berada dalam kawasan hutan, kawasan tersebut harus dikeluarkan dari kawasan hutan. Ketentuan lebih lanjut mengenai tata cara mengeluarkan wilayah masyarakat hukum adat dari Kawasan Hutan diatur dengan Peraturan Direktur Jenderal. Terhadap wilayah masyarakat hukum adat yang berada dalam kawasan hutan sesuai Peraturan Daerah Provinsi atau Kabupaten/Kota, maka wilayah masyarakat hukum adat dikeluarkan keberadaannya dari kawasan hutan.

Tanah hak ulayat masyarakat adat pun diakui dan dilindungi dalam UU No. 39 Tahun 2014 tentang Perkebunan. Pasal 103 menyebutkan bahwa "setiap pejabat yang menerbitkan Izin Usaha Perkebunan di atas Tanah Hak Ulayat Masyarakat Hukum Adat sebagaimana dimaksud dalam Pasal 17 ayat (1) dipidana dengan pidana penjara paling lama 5 (lima) tahun atau denda paling banyak Rp5.000.000.000,- (lima miliar rupiah)". Pasal 107 menyatakan bahwa "setiap orang yang secara tidak sah mengerjakan, menggunakan, menduduki, dan/atau menguasai tanah masyarakat atau Tanah Hak Ulayat Masyarakat Hukum Adat dengan maksud untuk Usaha Perkebunan dipidana dengan pidana penjara paling lama 4 (empat) tahun atau denda paling banyak Rp4.000.000.000,- (empat miliar rupiah)". Diakuinya kepemilikan hutan adat masyarakat adat oleh pemerintah akan menguntungkan masyarakat terutama dengan inistiatif $\mathrm{REDD}^{+}$. Hal penting yang diatur di dalam Peraturan Daerah tentang Kesatuan Masyarakat Hukum Adat adalah mengenai status 
dari hak individu, izin atau hak perusahaan, dan kawasan hutan yang telah lebih dulu ada pada wilayah adat sebelum Peraturan Daerah mengenai Penetapan Kesatuan Masyarakat Hukum Adat dibentuk.

UU Desa No. 6 Tahun 2014 secara khusus mengatur mengenai Desa adat dengan peraturan pelaksananya adalah PP No. 43 Tahun 2014 tentang Peraturan Pelaksanaan Undang-Undang No. 6 Tahun 2014 tentang Desa. UU Desa dapat dikatakan sebagai bentuk penghormatan dan pengakuan negara terhadap masyarakat adat. Ketentuan Desa adat diatur dalam Pasal 96-111. Pemerintah Pusat, Pemerintah Daerah Provinsi, serta Pemerintah Daerah Kabupaten Kota melakukan penataan kesatuan masyarakat hukum adat dan ditetapkan menjadi Desa adat. Pasal 97 menyebutkan Desa adat harus memenuhi syarat sebagai berikut.

(a) Kesatuan masyarakat hukum adat beserta hak tradisionalnya secara nyata masih hidup, baik yang bersifat territorial, genealogis maupun fungsional.

(b) Kesatuan masyarakat hukum adat beserta hak tradisionalnya dipandang sesuai dengan prinsip perkembangan masyarakat; dan

(c) Kesatuan masyarakat hukum adat beserta hak tradisionalnya sesuai dengan prinsip Negara kesatuan RI.

Kesatuan masyarakat hukum adat beserta hak tradisionalnya yang masih hidup harus memiliki wilayah dan paling kurang memenuhi salah satu atau gabungan unsur berikut ini.

(a) Masyarakat yang warganya memiliki perasaan bersama dalam kelompok;

(b) Pranata pemerintahan adat;

(c) Harta Kekayaan atau benda adat;

(d) Perangkat norma hukum adat.

Desa adat ditetapkan dengan Peraturan Daerah Kabupaten/Kota. Penggabungan desa adat dapat dilakukan atas prakarsa dan kesepakatan antardesa adat. Pemerintah Daerah Kabupaten Kota memfasilitasi pelaksanaan penggabungan desa adat. Status desa dapat diubah menjadi desa adat, kelurahan dapat menjadi desa adat, desa adat dapat menjadi desa, dan desa adat dapat dirubah menjadi kelurahan berdasarkan prakarsa masyarakat yang bersangkutan melalui Musyawarah Desa dan disetujui oleh Pemerintah Daerah Kabupaten Kota. Ketika desa diubah menjadi desa adat, kekayaan desa beralih status menjadi kekayaan desa adat. Ketika kelurahan berubah menjadi desa adat, kekayaan kelurahan beralih status menjadi kekayaan desa adat. Ketika desa adat berubah menjadi desa, kekayaan desa adat beralih status menjadi kekayaan desa. Ketika desa adat berubah menjadi kelurahan, kekayaan desa adat beralih status menjadi kekayaan pemerintah Kabupaten/Kota.

Kewenangan Desa adat meliputi:

(a) Pengaturan dan pelaksanaan pemerintahan berdasarkan susunan asli;

(b) Pengaturan dan pengurusan ulayat atau wilayah adat;

(c) Pelestaraian nilai sosial budaya desa adat;

(d) Penyelesaian sengketa adat berdasarkan hukum adat yang berlaku di desa adat dalam wilayah yang selaras dengan prinsip hak asasi manusia dengan mengutamakan penyelesaian secara musyawarah;

(e) Penyelenggaraan sidang perdamaian peradilan desa adat sesuai dengan ketentuan peraturan perundang-undangan;

(f) Pemeliharaan ketentraman dan ketertiban masyarakat desa adat yang berdasarkan hukum adat yang berlaku di desa adat; dan

(g) Pengembangan kehidupan hukum adat sesuai dengan kondisi sosial budaya masyarakat desa adat.

Peraturan terbaru yang terkait masyarakat hukum adat adalah Peraturan Menteri Agraria dan Tata Ruang No. 9/2015 tentang Tata Cara Penetapan Hak Komunal atas Tanah Masyarakat Hukum Adat dan Masyarakat yang Berada dalam Kawasan Tertentu. Peraturan ini mencabut peraturan sebelumnya, Peraturan No. $5 / 1999$. Peraturan ini mengubah prosedur permohonan penetapan Hak Komunal atas Tanah Masyarakat Hukum Adat dan Masyarakat yang Berada dalam Kawasan tertentu. Prosedur permohonan tersebut diawali dengan masyarakat hukum adat mengajukan permohonan kepada Bupati/Walikota atau gubernur diajukan oleh kepala adat, dengan dilengkapi syarat antara lain:

(a) Riwayat Masyarakat Hukum adat dan riwayat tanahnya apabila pemohon masyarakat hukum adat;

(b) Foto kopi kartu identitas atau akta pendirian koperasi, unit bagian dari desa atau kelompok masyarakat lainya;

(c) Surat keterangan dari kepala desa atau nama lain yang serupa dengan itu; 
Setelah menerima permohonan Bupati/ Walikota atau gubernur membentuk Tim IP4T untuk menentukan keberadaan masyarakat hukum adat. Tim IP4T terdiri dari:

(a) Kepala Kantor Pertanahan Kabupaten/Kota merangkap ketua;

(b) camat setempat;

(c) lurah/kepala desa setempat;

(d) unsur pakar hukum adat;

(e) perwakilan masyarakat adat setempat;

(f) Lembaga Swadaya Masyarakat;

(g) instansi yang mengelola sumber daya alam.

Tim IP4T bertugas menerima permohonan, melakukan identifikasi dan verifikasi pemohon, riwayat tanah, jenis penguasaan, pemanfaatan dan penggunaan tanah, mengidentifikasi dan menginventarisasi batas tanah, pemeriksaan lapangan, melakukan data analisis data yurisdiksi dan data fisik bidang tanah, serta menyampaikan hasil kerja Tim 1P4T. Tim IP4T menyampaikan hasil laporan ada atau tidaknya masyarakat hukum adat. Dalam hal tim IP4T menyatakan ada maka Bupati/Walikota menetapkan hak komunal atas tanah. Penetapan disampaikan kepada Kepala Kantor Pertanahan untuk didaftarkan hak atas tanahnya. Sertifikat hak atas tanah yang didaftarkan dapat diberikan atas nama anggota masyarakat hukum adat, pengurus koperasi atau unit bagian dari desa atau kepala adat.

Kementrian Lingkungan Hidup dan Kehutanan juga mengeluarkan peraturan No. P.32/Menlhk-Setjen/2015 tentang Hutan Hak. Pada saat Peraturan Menteri ini mulai berlaku, Peraturan Menteri Kehutanan No. P.26/MenhutII/2005 tentang Pedoman Pemanfaatan Hutan Hak dicabut dan dinyatakan tidak berlaku. Berdasarkan Putusan Mahkamah Konstitusi No. 35/PUU-X/2012, hutan adat yang merupakan bagian hutan hak belum diatur dalam Peraturan Menteri Kehutanan No. P.26/Menhut-II/2005. Pengaturan hutan hak dimaksudkan untuk memberikan jaminan kepastian hukum dan keadilan bagi pemangku hutan hak dalam mewujudkan kesejahteraan masyarakat dan pengelolaan hutan lestari. Hutan hak terdiri dari hutan adat dan hutan perseorangan/badan hukum. Untuk mendapatkan hutan hak, Pasal 4 menyatakan bahwa masyarakat hukum adat, baik perseorangan secara sendiri-sendiri maupun bersama-sama dalam kelompok atau badan hukum, mengajukan permohonan penetapan kawasan hutan hak kepada Menteri. Berdasarkan permohonan, menteri melakukan verifikasi dan validasi. Berdasarkan hasil verifikasi dan validasi, Direktur Jenderal atas nama menteri dalam waktu 14 (empat belas) hari kerja menetapkan hutan hak sesuai dengan fungsinya. Areal hutan hak yang telah ditetapkan sebagaimana dimaksud dicantumkan dalam peta kawasan hutan. Jika masyarakat tidak mengajukan permohonan penetapan hutan hak, menteri bersama pemerintah daerah melakukan identifikasi dan verifikasi masyarakat adat dan wilayahnya yang berada di dalam kawasan hutan untuk mendapat penetapan masyarakat hukum adat dan hutan adat.

Syarat permohonan penetapan hutan adat meliputi:

(a) Terdapat masyarakat hukum adat atau hak ulayat yang telah diakui oleh pemerintah daerah melalui produk hukum daerah;

(b) Terdapat wilayah adat yang sebagian atau seluruhnya berupa hutan;

(c) Surat pernyataan dari masyarakat hukum adat untuk menetapkan wilayah adatnya sebagai hutan adat; dan

(d) Jika produk hukum daerah sebagaimana dimaksud pada ayat (1) huruf a tidak mencantumkan peta wilayah adat, menteri bersama-sama pemerintah daerah memfasilitasi masyarakat hukum adat melakukan pemetaan wilayah adatnya.

Tiga peraturan yang terkait pengakuan hukum adat sebagai implementasi Keputusan MK No. 35/PUU/2012 yang menjadi landasan hukum bagi pengakuan masyarakat dan hak atas tanahnya yaitu Permendagri No. 52 Tahun 2014 tentang Pedoman Pengakuan dan Perlindungan Masyarakat Hukum Adat, Peraturan Menteri Agraria dan Tata Ruang No. 9/2015 tentang Tata Cara Penetapan Hak Komunal Atas Tanah Masyarakat Hukum Adat dan Masyarakat yang Berada dalam Kawasan Tertentu, serta Peraturan Menteri Lingkungan Hidup dan Kehutanan No. P.32/Menlhk-Setjen/2015 tentang Hutan Hak.

\section{Permasalahan yang Dihadapai Masyarakat Adat Enggano}

Permintaan diakuinya hak adat masyarakat Enggano oleh pemerintah daerah Bengkulu merupakan isu yang paling mengemuka saat ini di Enggano. Para kepala adat menginginkan hak adat mereka diakui melalui perda atau paling tidak dengan Surat Keputusan Bupati atau Surat Keputusan Kecamatan. Pemerintah Kabupaten 
Bengkulu Utara merencanakan pengakuan hak masyarakat adat Enggano dalam bentuk perda yang mulai diproses di DPRD pada tahun 2016. Beberapa permasalahan hak adat yang mengemuka dalam hasil wawancara, workshop, dan FGD antara lain:

(a) Adanya lembaga adat desa versi pemerintah yang berbeda dengan lembaga adat asli masyarakat Enggano. Terhadap dualisme lembaga adat ini, tokoh-tokoh adat meminta pembubaran lembaga adat desa versi pemerintah. Menurut tokoh adat, hanya ada satu kelembagaan adat di Enggano yaitu lembaga adat yang cakupannya untuk seluruh masyarakat Enggano. Secara adat, tidak ada lembaga adat independen di level desa;

(b) Terdapat konflik terkait status tanah ulayat dikarenakan ketidaksingkronan pemerintah dengan adat. Legalitas tanah dalam SKT (Surat Keterangan Tanah) ditetapkan Pemerintah Desa tanpa adanya koordinasi dengan lembaga adat yang menaungi keseluruhan desa-desa di Kecamatan Enggano. Pengurusan SKT sampai saat penelitian, dilakukan oleh Pemerintah Desa hanya dengan sepengetahuan/izin dari lembaga adat desa yang merupakan bentukan dari lembaga di kabupaten/kecamatan. Seperti disebutkan di atas, tokoh-tokoh adat menganggap pembentukan lenbaga adat desa ini menyalahi pengaturan adat yang sesungguhnya;

(c) Penjualan tanah adat kepada orang luar/ pendatang;

(d) Adanya keinginan para kepala suku terhadap pembentukan desa adat. Namun, permasalahannya adalah pembentukan desa adat memerlukan proses yang panjang. Dari keseluruhan lima suku asli dan satu suku pendatang, ada kekhawatiran dari suku pendatang bahwa dengan wacana pembentukan desa adat tersebut maka tanah adat harus dikembalikan ke asalnya. Suku Kaamay, yang merupakan pendatang, mendapatkan pemberian tanah dari suku asli Enggano. Jika pengembalian tanah tersebut berlaku, hal ini akan mempersulit posisi Suku Kaamay. Permasalahan yang lain adalah dulu hukum adat berlaku per kawasan. Namun, sekarang sudah berbaur menjadi satu. Masyarakat adat pun sekarang tidak berdiam di lokasi tanah adatnya. Suku Kaarubi tinggal di Desa Banjarsari, tempat banyak suku Kaamay berdiam. Selain itu,
Kepala Suku Kauno tinggal di Kahyapu dan sudah berbaur dengan masyarakat di Kahyapu;

(e) Keinginan adanya pengaturan dan penetapan pengakuan serta perlindungan hak ulayat melalui peraturan daerah.

\section{Sejarah Singkat Masyarakat Adat Enggano}

Berdasarkan sejarahnya, nenek moyang penduduk di Enggano terdiri dari tiga suku. Suku yang tertua adalah: Suku Kahowao, Suku Kaitora, dan Kaarubi. Kemudian terjadi perpecahan suku: Suku Kahawoa pecah dan melahirkan suku baru, yaitu Suku Kauno, Suku Kaarubi pecah dan melahirkan suku baru, yaitu Suku Kaaruba. Pada awal perpecahan, terdapat 44 cabang suku. Akan tetapi, dengan menurunnya populasi akibat wabah penyakit dan kematian, suku cabang berkurang menjadi lima suku saja. Tiap suku mempunyai badan hukum adat dengan dipimpin oleh seorang kepala adat. Tiap-tiap suku mempunyai tapal batas hak atas tanah. Batasbatas hak atas tanah dilindungi oleh hukum perang antarsuku. Apabila ada suku yang melanggar kemudian terjadi perang. Setelah adanya agama dan pemerintah, kini sudah tidak ada lagi perang.

Masyarakat Enggano memiliki adatistiadat dan bahasa sendiri yang berbeda dengan suku lain. Mereka juga memiliki identitas sebagai Orang Enggano dengan prinsip keturunan matrilineal dan mempunyai simbol nama suku di belakang nama seseorang. Ada lima suku asli di Enggano, yaitu Suku Kaahowao, Suku Kauno, Suku Kaitora, Suku Kaarubi, dan Suku Kaaruba. Identitas suku seseorang bisa dilihat dari nama belakang sukunya, seperti Rafly Zei Kaitora, Zulkifli Kaaruba, Fiterjun Kaahowao, Alkadius Kauno, dan Arifin Kaarubi. Sementara itu, satu suku pendatang diberi nama suku Kaamay. Keenam suku sekarang tinggal di desa-desa di wilayah Enggano. Ada enam desa, yaitu Desa Banjarsari dan Desa Kahyapu; di kedua desa ini kebanyakan tinggal suku Kaamay, Desa Kaana yang banyak dihuni oleh Suku Kaarubi, serta Desa Meok, Malakoni, dan Apoho; tempat yang banyak ditinggali oleh Suku Kaitora. 


\section{Wilayah Darat dan Laut yang Diakui sebagai Wilayah Adat}

Wilayah merupakan hal yang krusial dalam pengakuan adat Enggano. Myrna Safitri (2015) mengatakan bahwa wilayah adat yang berfungsi sebagai ruang kehidupan dan sebagai alamat kebudayaan sekarang ini wilayah adat menjadi terancam dan menjadi arena konflik. Salah satu persyaratan untuk dibentuk desa adat atau pengakuan hak adat oleh pemerintah daerah adalah adanya wilayah (Pasal 97 (2) UU Desa). Bisa dipastikan bahwa masyarakat Enggano masih memiliki wilayah ulayat. Namun demikian, kami menemukan konsepsi yang berbeda-beda tentang unit dan batas-batasnya. Pabuki, dalam wawancara yang dilakukan bulan Juni 2015 mengklaim bahwa 100\% Pulau Enggano adalah wilayah adat masyarakat Enggano. Namun, kepala desa menganggap sebagian wilayah itu ada dalam otoritas pemerintahan desa. Peta pemerintah pun memiliki perbedaan dengan peta adat (peta pusat dan peta tata ruang).

Sebenarnya, pemetaan partisipatif yang dilakukan oleh NGO - dalam hal ini adalah WALHI-dan Masyarakat Adat telah dilakukan pada tahun 2007. Peta tersebut ditandatangani oleh kepala desa dan camat yang menjabat pada waktu itu. Namun, peta ini tidak diakui oleh kepala desa dan camat yang menjabat pada saat sekarang. Padahal pemetaan wilayah adat di setiap kampung/desa sampai saat ini belum ada; hanya ada pemetaan secara global. Menurut penjelasan WALHI, kesalahan terletak pada tidak disosialisasikannya peta ke desa, tetapi hanya disimpan di Pabuki. Berdasarkan ketentuan yang telah dipaparkan pada bagian sebelumnya, memang seharusnya pemerintah daerah melakukan pemetaan terhadap hak ulayat masyarakat hukum adat di daerah yang bersangkutan sehingga ada legitimasi terhadap hak ulayat tersebut dari pemerintah.

\section{Wilayah Ulayat Masyarakat Adat Enggano}

Masyarakat Adat Enggano menyebut tanah ulayat dengan Tanah Kaudar dan mengklaim bahwa wilayah adat meliputi $100 \%$ wilayah Enggano beserta pulau-pulaunya. Di bawah ini adalah salah satu contoh peta tata ruang hasil pemetaan partisipatif yang pembuatannya dibantu oleh WALHI. Dari peta tersebut dapat terlihat secara jelas bahwa wilayah ulayat merupakan lahan yang terluas.
Terkait persoalan hutan adat, sampai saat ini masih terdapat perbedaan antara masyarakat dengan BKSDA. Masyarakat mengklaim bahwa hutan konservasi (cagar alam) dan hutan buru yang dikelola oleh BKSDA merupakan hutan adat. Berdasarkan hal ini, masyarakat menginginkan untuk meminta kembali hutan konservasi yang dikelola BKSDA menjadi hutan adat. Di lain pihak, berdasarkan wawancara dengan staff dari BKSDA, masyarakat adat sudah melimpahkan hutan adat untuk dikelola pemerintah pada zaman pemerintahan Soeharto. Tabel di bawah ini memperlihatkan rincian peruntukan lahan kehutanan di Pulau Enggano berdasarkan sumber Dinas Kehutanan Provinsi Bengkulu.

Luas Pulau Enggano adalah kurang lebih 40.600 ha. Dari hasil kajian WALHI, didapatkan informasi bahwa wilayah ulayat adalah seluas 14.934,523 ha. Adapun rencana tata ruang penggunaan lahan di Pulau Enggano berdasarkan kajian dan pengamatan WALHI adalah sebagai berikut. $^{2}$

Tabel 2.

Rencana Penggunaan Lahan di Pulau Enggano

\begin{tabular}{|c|l|c|}
\hline No & \multicolumn{1}{|c|}{ Peruntukan lahan } & Luas (Ha) \\
\hline 1 & Wilayah Ulayat & $14.934,523$ \\
\hline 2 & Hutan Waru & 64,936 \\
\hline 3 & $\begin{array}{l}\text { Areal Perkebunan } \\
\text { Masyarakat }\end{array}$ & $6.759,464$ \\
\hline 4 & Areal Persawahan & $1,260,904$ \\
\hline 5 & Hutan Bakau & 400,733 \\
\hline 6 & Hutan Keramat & 729,287 \\
\hline 7 & Hutan Nimbung & $10,118,388$ \\
\hline 8 & $\begin{array}{l}\text { Kawasan yang } \\
\text { dilindungi }\end{array}$ & 44,479 \\
\hline 9 & Kampung & 4,048 \\
\hline 10 & Danau & $37.853,350$ \\
\hline \multicolumn{2}{|c|}{ Jumlah } \\
\hline
\end{tabular}

Sumber: WALHI Bengkulu, 2007

Berdasarkan wawancara dengan Pabuki, wilayah adat per suku meliputi wilayah sebagai berikut:

${ }^{2}$ Kementrian Perencanaan Pembangunan Nasional Bappenas, Pengembangan Pulau Enggano sebagai Pusat Industri Berbasis Maritim dan Pariwisata di Provinsi Bengkulu, 2004 
Peta 1.

Peta Kawasan Adat Pulau Enggano

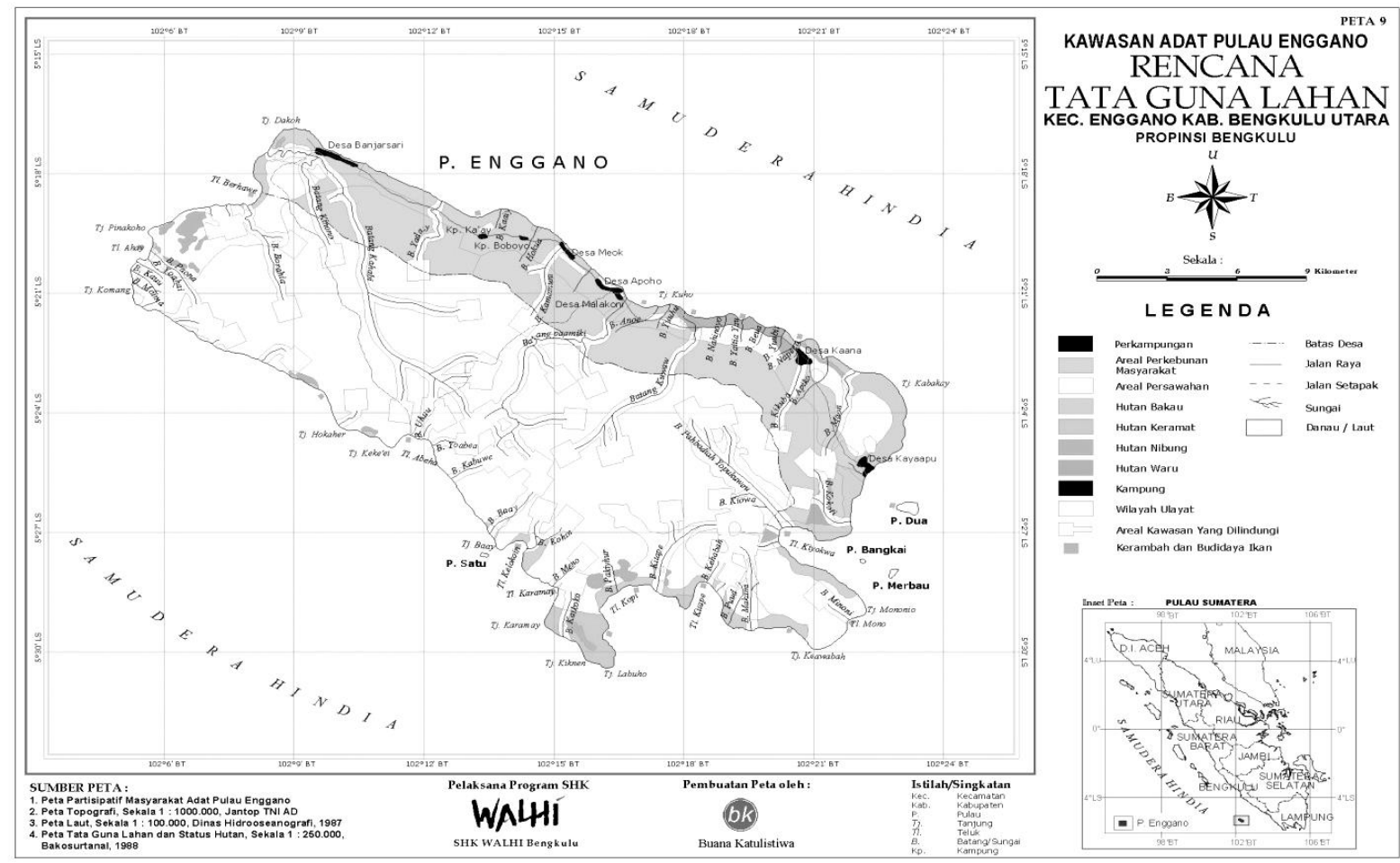

Sumber: Peta WALHI, 2007

Tabel 1.

Peruntukan Lahan Kehutanan di Pulau Enggano

\begin{tabular}{|c|l|c|c|}
\hline No & Peruntukan & Luas $(\mathrm{Ha})$ & Lokasi \\
\hline 1 & Hutan produksi terbatas & $5.601,00$ & Hulu Malakoni \\
\hline 2. & Hutan Lindung & $3,450,00$ & Koko Buwa Buwa \\
\hline 3. & Cagar Alam & 305,00 & Tanjung Laksana \\
\hline 4. & Cagar Alam & 333,28 & Sungai Bahewo \\
\hline 5. & Cagar Alam & 495,06 & Talang Klowe \\
\hline 6. & Cagar Alam & 331,23 & Gunung Nanu a \\
\hline 7. & Taman Buru & $7,271,57$ & \\
\hline \multicolumn{2}{|c|}{ Jumlah } & $17.786,57$ & \\
\hline
\end{tabular}

Sumber: Dinas Kehutanan Provinsi Bengkulu, 2003²

\begin{tabular}{|l|l|}
\hline \multicolumn{1}{|c|}{ Suku } & \multicolumn{1}{c|}{ Wilayah Adat } \\
\hline Kahua & Wilayah Kabaau (sekarang Desa Apoho) \\
\hline Kauno & Nayo ---desa Malakoni \\
\hline & Maham ---Boboyo (Desa Meok) \\
\hline & Pabuuy ---- desa Meok \\
\hline Kaitora & kampong tengah (Pahua) desa Meok \\
\hline Kaaruba & (Kaanai) sekarang desa Kaana \\
\hline Kaarubi & $\begin{array}{l}\text { Ahipe-----tumpukan material simpang } \\
\text { tiga (Desa Malakoni) }\end{array}$ \\
\hline & Kanaine ---- pak Imam desa Malakoni \\
\hline Kamaay & $\begin{array}{l}\text { Dusun Abuba ----lokasi jembatan } \\
\text { rambutan desa Meok } \\
\text { Barat: Desa Banjar Sari, Wilayah Timur } \\
\text { (Desa Kayapu- Kampung Kertajaya). }\end{array}$ \\
\hline
\end{tabular}

Kekhawatiran Suku Kaamay adalah pembentukan desa adat akan merampas hak atas tanah mereka karena dahulu tanah itu merupakan wilayah adat. Sebenarnya, kekhawatiran akan berpindahnya SKT menjadi tanah adat tidak beralasan karena tanah-tanah yang telah memiliki SKT telah dikeluarkan dari hak wilayah adat. Keberadaan tanah ulayat masyarakat hukum adat yang masih ada dinyatakan dalam peta dasar pendaftaran tanah dengan membubuhkan suatu tanda kartografi, dan apabila memungkinkan, menggambarkan batas-batasnya serta mencatatnya dalam daftar tanah.

Sumber: Wawancara dengan Pabuki, 2015 


\section{Wilayah Laut Masyarakat Adat Enggano}

Dari Peraturan Adat Enggano yang telah didokumentasikan, memang tidak diatur mengenai hak ulayat laut. Berdasarkan hasil wawancara dengan masyarakat, diketahui bahwa tidak ada pengaturan mengenai kepemilikan suatu suku terhadap wilayah laut tertentu. Di dalam peraturan adat yang sudah didokumentasikan juga tidak diatur mengenai kepemilikian suatu suku terhadap wilayah ulayat lautnya. Jadi, dapat dikatakan wilayah laut Enggano dikelola bersama-sama oleh keenam suku dan dapat dimanfaatkan oleh setiap suku. Wilayah perairan Pulau Enggano adalah wilayah perairan di sekitar Enggano dengan jarak kurang lebih 3 mil laut $(5 \mathrm{~km})$ dari garis pantai Pulau Enggano. Jika ada kapal asing yang sudah terdampar di wilayah perairan Enggano dan sudah tidak dapat diselamatkan oleh pemiliknya, kapal itu akan menjadi milik masyarakat adat dan mereka berhak untuk memanfaatkannya. Selian itu, nelayan asing juga dilarang mengambil hasil laut di wilayah perairan Pulau Enggano.

\section{Hukum dan Peraturan Adat Enggano Terkait Pengelolaan SDA}

Untuk dapat diakuinya hak adat atau desa adat, hal penting lainnya yang perlu diperhatikan adalah adanya penerapan hukum adat. Ada beberapa hukum adat di Enggano, baik yang tidak tertulis maupun yang telah didokumentasikan, beserta sanksi adatnya. Misalnya, hukum adat yang mengatur aspekaspek kehidupan masyarakat adat Enggano, mulai dari perkawinan, kematian, usaha atau kegiatan, harta perkawinan, harta warisan, perzinaan, kesopanan, perkelahian, pembunuhan, ketertiban umum, sawah kebun dan pekarangan, binatang ternak, dan kepemilikan lahan. Aturanaturan adat ini masih dipatuhi oleh, paling tidak, sebagian anggota masyarakat adatnya.

Hukum adat yang akan dibahas dalam artikel ini hanya menyangkut aturan-aturan adat yang terkait dengan kelestarian sumber daya alam di Enggano, khususnya terkait dengan isu eksploitasi sumber daya alam yang dapat mengancam Pulau Enggano. Kebakaran hutan, penambangan pasir, dan pembalakan liar yang sekarang terjadi merupakan ancaman yang serius terhadap kelestarian sumber daya di Pulau Enggano. Peraturan terkait kelestarian sumber daya alam terdapat dalam Keputusan Kepala Suku No. 02/KPS/Ka.S/2009 tentang Pengolahan sumber daya alam, satwa dan hewan, serta pembukaan lahan, pengolahan dan pelestarian kawasan pesisir Pulau Enggano dalam upaya penyelamatan Pulau Enggano dari ancaman abrasi. Masyarakat adat menyadari bahwa Pulau Enggano adalah pulau yang rentan sehingga keseimbangan ekosistemnya harus dijaga. Eksploitasi besar-besaran terhadap pulau Enggano akan membahayakan keberadaan pulau tersebut dan juga penghuninya. Peraturan adat ini telah didokumentasikan atas inisiasi dari AMAN Bengkulu. Berikut ini akan dijelaskan peraturan-peraturan adat tersebut.

\section{a. Pembukaan Lahan/Hutan}

Peraturan pembukaan lahan diatur dalam aturan adat. Pembukaan lahan kebun dapat diberi izin kepada setiap kepala keluarga seluas 1 ha dengan ketentuan sebagai berikut.

(1) Harus mendapat izin dan persetujuan dari kepala desa dan kepala-kepala suku sesuai dengan kawasan dan suku yang akan dibuka;

(2) Tidak dibenarkan bagi warga, baik asli maupun pendatang, memperjualbelikan lahan/tanah dan hutan kepada siapapun kecuali tanaman yang tumbuh di atas tanah tersebut;

(3) Jarak 100 meter dari kepala (di atas tanah yang sudah di tanami) tidak dibenarkan dibuka oleh siapapun tanpa seizin pemilik tanah tersebut. Warga yang membuka lahan berkelompok (5-10 orang) harus mengadakan kenduri adat (kata pamit).

Dalam peraturan adat, setiap kepala keluarga hanya diperbolehkan membuka lahan sebesar satu hektar. Namun, pada kenyataanya banyak yang membuka lahan lebih dari satu hektar. Bahkan ada yang membuka lahan dua hektar. Ada kesimpangsiuran di masyarakat mengenai berapa hektar lahan yang boleh dibuka. Dari wawancara dengan beberapa penduduk diperoleh informasi bahwa pendatang diberi izin untuk membuka lahan sebanyak dua hektar. Tentu saja jika hal ini terjadi maka bertentangan dengan aturan adat yang semestinya hanya satu hektar. Pembukaan lahan yang luas yang diberikan kepada pendatang akan mengakibatkan banyak hutan yang dibuka. Jika hal tersebut tidak diatur, akan terjadi pembukaan lahan yang lebih besar di Enggano yang mengancam keberlangsungan ekosistem. Pembukaan lahan di Pulau Enggano harus dilakukan berdasakan prinsip kehati-hatian, karena 
berdasarkan rekomendasi Komisi Amdal Provinsi Bengkulu, Pulau Enggano tidak layak dijadikan perkebunan besar, seperti kelapa sawit.

Menurut aturan adat, pelanggaran bagi ketentuan di atas akan dikenai sanksi sebagai berikut.

(1) Denda adat dalam bentuk uang sebesar Rp500.000,-;

(2) Melaksanakan upacara adat yang ditentukan oleh para kepala suku;

(3) Pihak yang melanggar diserahkan kepada pemerintah setempat untuk diproses sesuai hukum yang berlaku;

(4) Tanah yang dibuka harus ditinggalkan dan diserahkan kembali kepada para kepala suku/pemerintah desa setempat.

\section{Perlindungan Hewan}

Peraturan adat juga mengatur mengenai perlindungan hewan seperti burung-burung, kerbau, sapi liar, dan rusa.

\section{(a) Burung}

Disebutkan bahwa setiap warga tidak dibenarkan mengambil anak-anak burung (burung Beo, Betet, Kukpan, dan sejenisnya) pada tahun ganjil kecuali pada tahun genap. Tidak dibolehkan menangkap atau menembak induk burung Beo, Betet, Pergam, dengan memakai senjata api dan sejenisnya. Sanksi kepada yang melanggar dikenakan denda sebesar Rp 500.000,- per ekor.

\section{(b) Kerbau dan Sapi Liar}

Kerbau dan sapi liar yang ada di hutan Enggano pada mulanya milik anggota masyarakat Enggano yang dilepas pada tahun 1947. Sampai saat ini hewan-hewan tersebut telah berkembang biak di hutan dan dimiliki oleh lima kepala suku. Kerbau-kerbau ini dilarang keras untuk ditangkap oleh anggota masyarakat pendatang maupun asli Enggano, baik secara manual apalagi memakai senjata api. Anggota masyarakat Enggano yang ingin menangkap sapi atau kerbau di hutan harus mendapat persetujuan dari Lembaga Adat Pulau Enggano (Pabuki dan pemerintah setempat). Sanksi bagi yang melanggar adalah denda Rp2.500.000,- per ekor dan kepadanya diharuskan melakukan upacara adat untuk meminta maaf kepada para kepala suku.

\section{(c) Rusa}

Dilarang keras menangkap rusa dengan cara apapun di hutan Pulau Enggano tanpa mendapat izin resmi dari pemerintah dan para kepala suku. Sanksi bagi yang melanggar ketentuan adat sebesar Rp25.000.000,- dan melaksanakan perdamaian dengan para kepala suku. Sanksi dalam peraturan ini sangat besar dan jika ada anggota masyarakat yang melanggarnya, ada kemungkinan mereka tidak bisa membayarnya.

\section{b. Perlindungan Laut}

Perlindungan laut juga menjadi perhatian dalam aturan adat Enggano. Disebutkan bahwa buaya/penyu dilarang diperjualbelikan. Masyarakat Enggano diperbolehkan membudidayakan buaya tetapi sesuai dengan ketentuan tata cara adat Pulau Enggano yang berlaku. Penangkapan penyu oleh masyarakat Enggano khusus diperbolehkan bagi acara adat ataupun pesta adat dan sekedar kebutuhan acara pesta adat tersebut.

Pada kenyataanya, terdapat pertentangan antara aturan BKSDA dan peraturan adat. Peraturan adat membolehkan penangkapan dan konsumsi penyu untuk keperluan adat, sedangkan peraturan BKSDA melarang penangkapan penyu karena penyu termasuk hewan yang dilindungi. Hal tersebut membuat BKSDA berkompromi dengan masyarakat. Penangkapan penyu hanya diperbolehkan untuk keperluan adat dan dibatasi jumlah penangkapannya. Memang jika berdasarkan ketentuan peraturan perundang-undangan, penyu dilarang untuk dikonsumsi dengan tujuan untuk melindungi habitatnya dari kepunahan. Untuk itu, penyuluhan kepada masyarakat mengenai pengganti penyu dalam upacara adat mungkin dapat menjadi pertimbangan atau pembicaraan antara pemerintah dengan adat.

Sanksi dari praktik pengambilan penyu ini adalah dikenakan denda adat sebesar Rp2.500.000,- dan membuat upacara adat. Bagi yang menangkap buaya dan katung tanpa seizin pemerintah setempat dan kepala suku, maka akan diproses secara hukum yang berlaku. Akan tetapi, belum terdengar ada orang yang terkena adat sanksi yang begitu besar dari penangkapan penyu ini.

Aturan adat juga memuat larangan untuk mengambil ikan, baik di sungai maupun di laut, dengan menggunakan alat potassium, bom, alat 
setrum, pukat harimau, dan sejenisnya. Sanksi bagi yang melanggar adalah sebesar Rp10.000.000,-. Alat-alat yang digunakan akan disita dan diserahkan kepada pemerintah untuk diproses sesuai hukum yang berlaku. Sanksi dalam peraturan ini sangat berat dan kemungkinan lebih berat dari peraturan perundang-undangan. Namun, memang belum terdengar adanya nelayan yang dikenai sanksi terkait penggunaan alat-alat yang tidak ramah lingkungan.

Hal yang menjadi perhatian pemerintah dan Tim Penelitian LIPI adalah banyaknya penggunaan karang laut untuk pembangunan rumah. Hal ini sebenarnya tidak diperbolehkan oleh aturan pemerintah dan adat. Namun, karena ketiadaan alternatif bahan pembangunan rumah, maka masyarakat masih mengunakan karang laut. Karang laut digunakan dalam pembuatan rumah karena untuk mendatangkan batu dari Bengkulu membutuhkan biaya yang mahal. Peraturan adat sebetulnya melarang keras kepada siapapun untuk: (1) Mengambil batu karang di laut dan pasir di pantai di tempat pemukiman penduduk; (2) Menggunakan pasir pantai dan karang laut bersekala besar untuk pembangunan di Pulau Enggano. Bagi yang melanggar akan dikenai sanksi adat, yaitu membayar denda Rp100.000,- per kubik serta batu pasir harus dikembalikan ke asalnya.

Jika kita melihat peraturan resmi pemerintah, Enggano telah ditetapkan sebagai pencadangan kawasan konservasi perairan daerah Enggano berdasarkan Keputusan Bupati No. 175 Tahun 2014. Mengacu pada hasil survey Dinas Kelautan dan Perikanan, diketahui bahwa kawasan Enggano memiliki keanekaragaman hayati yang tinggi sehingga perlu dilindungi dan dikelola secara berkesinambungan serta dimanfaatkan untuk kepentingan wisata perairan dan rekreasi. Pencadangan kawasan konservasi di Perairan Enggano berada di wilayah Kecamatan Enggano yang terdiri dari:

(1) Lokasi I terletak antara Talang EngganoTanjung Labula, termasuk Pulau Dua, Pulau Merbau, dan Pulau Bangkai dengan luas 20.512,183 ha;
(2) Lokasi II terletak antara Tanjung LakshaTanjung Koomang dengan luas 16.6555,21 ha.

\section{c. Pemungutan Hasil Hutan dan Kayu}

Dalam peraturan adat disebutkan bahwa semua jenis kayu yang terdapat di Pulau Enggano tidak boleh diperjualbelikan keluar Pulau Enggano, apapun bentuk dan ukurannya, tanpa mendapat persetujuan dari para kepala suku dan pemerintah setempat. Kayu Kase, Trok, dan Apua tidak dibenarkan untuk ditebang dan dimusnahkan karena kayu tersebut adalah tanaman tumbuh masyarakat adat Pulau Enggano. Penduduk asli Enggano yang akan membangun rumah di luar Enggano diperbolehkan mengambil kayu Enggano sebatas $5 \mathrm{~m}^{3}$ untuk keperluan bangunan rumah sendiri, dengan ketentuan:

(1) Ada izin dari kepala suku melalui Pabuki Ketua Lembaga Adat Pulau Enggano;

(2) Mendapatkan izin dari pemerintah setempat (kepala desa);

(3) Pohon Nibung yang berada di pesisir Pulau Enggano yang berjarak 100 meter dari pantai tidak dibenarkan untuk diambil atau ditebang;

(4) Bagi masyarakat yang ingin menggunakan atau menebang pohon Nibung diberi izin mengambil sebanyak 100 batang pohon yang berada 200 meter dari pantai dan sungai.

Bagi yang melanggar ketentuan di atas akan dikenakan sanksi adat, yaitu membayar denda Rp25.000.000,- dan kayu yang telah diambil akan disita.

\section{Lembaga Adat Enggano Versus Lembaga Adat Desa}

Masyarakat Enggano memiliki lembaga adat sendiri. Pabuki merupakan ketua Lembaga Adat tertinggi sekecamatan Enggano dan menjabat selama tiga tahun. Tugasnya adalah mengkoordinasi seluruh kepala suku dan kepala suku pintu (ekkapu kaudarra). Di bawah Pabuki ada kepala suku dan kepala suku pintu serta kaumnya. Kepala adat dan kepala suku pintu dipilih untuk jangka waktu seumur hidup. 
Diagram 1.

Lembaga Adat Enggano

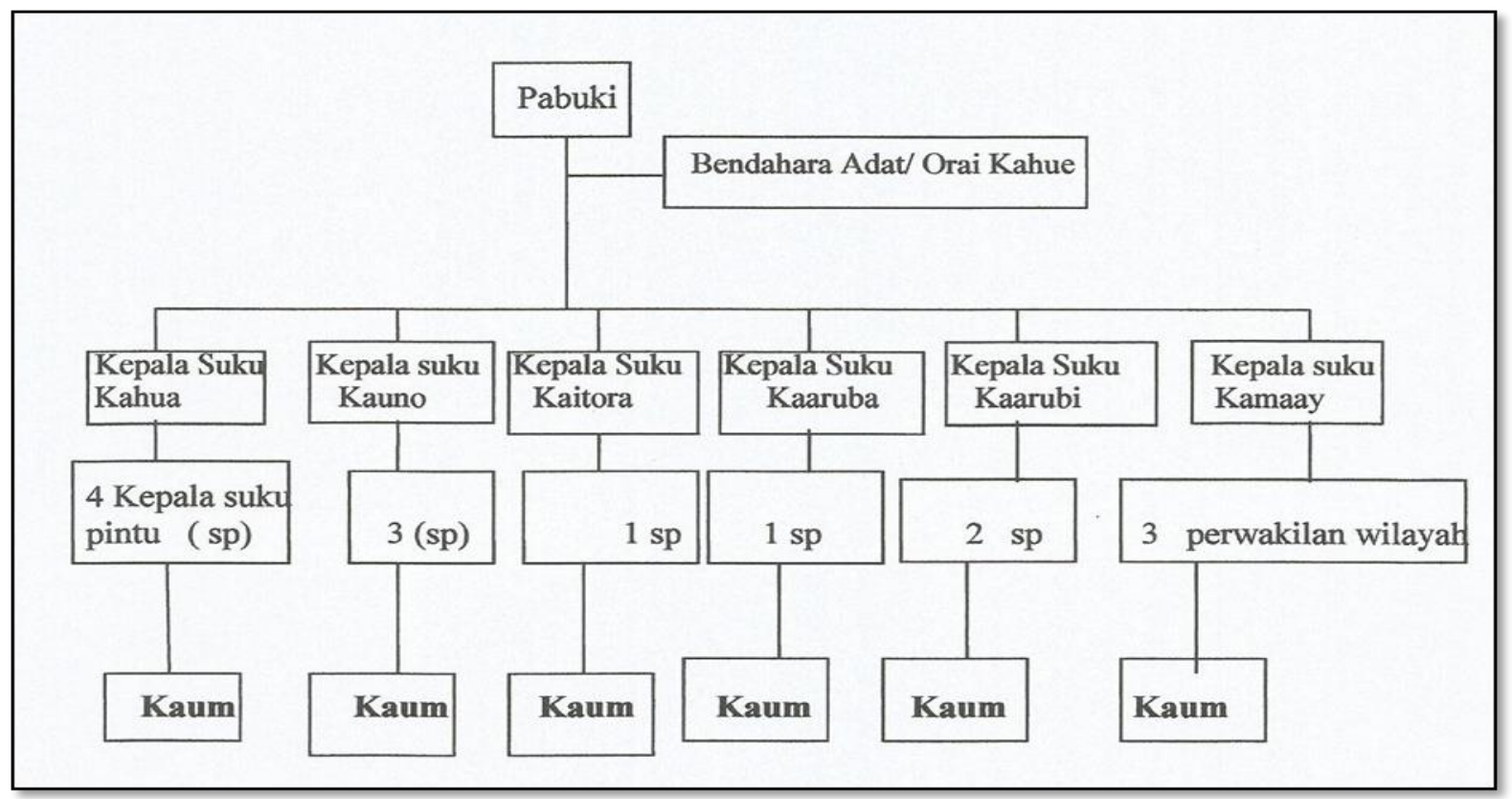

Sumber: Wawancara dengan Pabuki

Nama-Nama yang duduk di Lembaga Adat Masyarakat Enggano saat ini adalah sebagai berikut.

(a) Pabuki: Harun Kaarubi;

(b) Kepala suku Kaahowua: Djohri;

(c) Kepala Suku Pintu: Sabri, A. Khalik, Peter Jun, Musa;

(d) Kepala Suku Kauno: A. Malik;

(e) Kepala Suku Pintu: A. Besatri Kauno, Mulyadi Kauno, Armaedi Kauno;

(f) Kepala Suku Kaitora: M Rafli Zein;

(g) Kepala Suku Pintu: Ichanthenius;

(h) Kepala Suku Kaaruba: Zulkifli Kaaruba;

(i) Kepala Suku Pintu: Abidin;

(j) Kepala Suku Kaarubi: Sukaedi;

(k) Kepala Suku Pintu: Abner, Harun Kaarubi, Johansen;

(l) Kepala Suku Kaamay: Samsudin;

(m) Perwakilan Wilayah Tengah: Desis Manalu, Perwakilan wilayah Barat (Banjar sari): Simatupang, Wilayah Timur (Kayapu): Miskat.

Tugas dan fungsi masing-masing kedudukan pada lembaga adat adalah sebagai berikut.

(a) Fungsi Pabuki adalah mengkoordinasi seluruh ekappu kaudarra dan menyelesaikan semua permasalahan yang tidak dapat diselesaikan di tingkat ekkapu kaudarra. Wewenangnya adalah menjatuhkan sanksi kepada pihak yang melanggar hukum adat. Kewajibannya adalah menyampaikan aspirasi masyarakat kaaf kaudar kepada pihak yang terkait;

(b) Ekappu kaudarra berfungsi sebagai pimpinan di kaudarnya dan memiliki wewenang mengangkat dan memberhentikan Pabuki apabila melakukan pelanggaran berat atas dasar musyawarah seluruh kaaf kaudar tanpa menunggu jabatan berakhir. Selain itu, ia dapat menjatuhkan sanksi kepada warga sukunya dan pihak lain yang melanggar ketentuan hukum adat;

(c) Orai /Kahue berfungsi sebagai bendahara, sekretaris, humas kaudara. Wewenang yang dimilikinya adalah mengumpulkan danadana untuk kegiatan dalam kaudarnya.

Di sisi lain, Pemerintah desa telah membentuk lembaga adat desa yang berbeda keanggotaanya dengan lembaga adat masyarakat yang sudah ada. Hal ini memicu konflik dengan lembaga adat yang sekarang ada. Memang dalam UU Desa Pasal 95 diatur mengenai Lembaga Adat Desa. Pemerintah desa dan masyarakat desa dapat membentuk lembaga adat desa. Lembaga adat desa yang dimaksud merupakan lembaga yang menyelenggarakan fungsi adat istiadat dan menjadi bagian dari susunan asli desa yang tumbuh dan berkembang atas prakarsa masyarakat desa. Lembaga Adat Desa bertugas membantu Pemerintah Desa dan sebagai mitra 
dalam memberdayakan, melestarikan, dan mengembangkan adat istidat sebagai wujud pengakuan terhadap adat istidat masyarakat desa.

Pembentukan Lembaga Adat versi desa itu berdasarkan Surat Edaran Kepala Badan Pemberdayaan Masyarakat dan Pemerintahan Desa (BPMPD) Kabupaten Bengkulu Utara No. 411.6/150/BPMPD/III.I/2013 tanggal 15 April 2013. Dalam surat edaran tersebut, camat diminta agar memerintahkan kepala desa dalam wilayah masing-masing untuk membentuk lembaga adat yang ada di desa dengan tujuan mendukung kelancaran penyelenggaraaan pemerintahan dan pembangunan. Data tersebut diserahkan kepada BPMPD paling lambat 24 Februari 2014. Dalam aturan tersebut dicontohkan bagaimana membuat keputusan kepala desa dan strukturnya. Sebagai contoh, Keputusan Kepala Desa... Nomor... Tahun 2014 tentang Pembentukan Kepengurusan Lembaga Adat Desa dan Kelurahan Kabupaten Bengkulu Utara. Contoh Struktur Lembaga Adat versi Pemerintah adalah sebagai berikut.

Diagram 2.

Lembaga Adat Desa

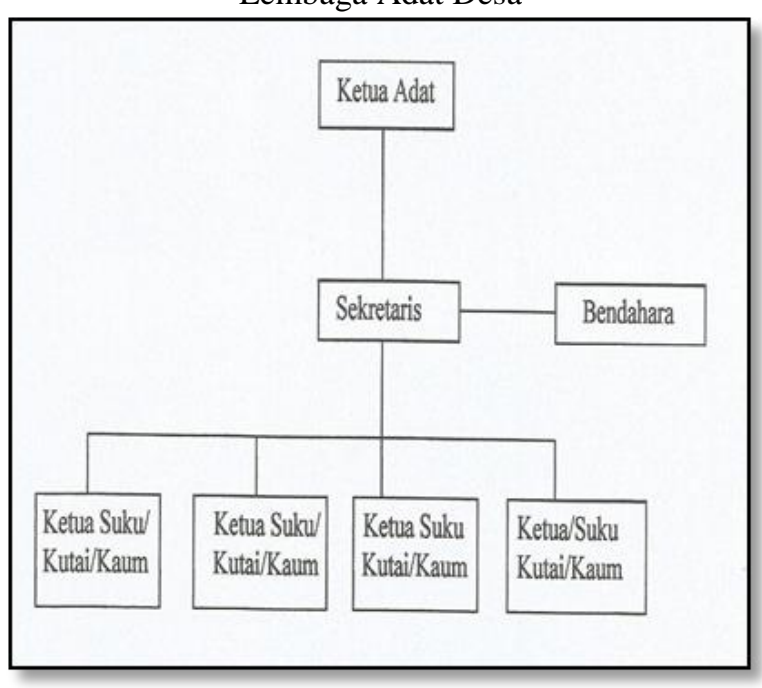

Sumber: BPMPD Enggano, 2013

Lembaga Adat versi pemerintah ini berfungsi sebagai mitra pembangunan desa dan pemelihara adat istiadat. Namun demikian, para kepala adat Enggano dan Lembaga Adat Enggano merasa keberatan terhadap pembentukan lembaga adat desa bentukan pemerintah tersebut. Hal ini disebabkan orang-orang dan struktur pada lembaga adat desa berbeda dengan lembaga adat yang ada, sehingga mereka meminta lembaga adat desa bentukan pemerintah untuk dibubarkan saja.

\section{Peradilan Adat Masyarakat Enggano}

Di dalam masyarakat Enggano terdapat peradilan adat. Jika terjadi silang adat, misalnya pada kasus penyerobotan tanah, dapat diselesaikan secara adat. Pabuki mengundang seluruh kepala suku, pihak yang bersengketa, camat sebagai penasihat, serta tokoh adat yang mengetahui persoalan tanah. Dua per tiga dari pihak yang hadir mengambil keputusan melalui mekamisme voting.

Kasus penyerobotan tanah di Enggano memang seringkali terjadi. Pada saat penulis bersama tim melakukan penelitian, kami menemukan sidang adat mengenai penyelesaian penyerobotan tanah. Pabuki sebagai koordinator Kepala Adat se-Enggano mengundang para pihak yang berselisih, termasuk kepala-kepala adat dan tokoh-tokoh adat yang mengetahui mengenai status tanah serta camat sebagai pihak dari Pemerintah.

Kasus yang mengemuka adalah kasus diperjualbelikannya sejumlah tanah ulayat adat Enggano sebanyak 20 hektar di lokasi Desa Banjar Sari dan Desa Meok. Kasus itu diajukan ke pihak kepolisian, tetapi oleh polisi kasus ini dikembalikan kepada masyarakat adat untuk diselesaikan secara adat. Dari hasil kesepakatan kepala suku adat, tanah yang dibabat dikembalikan kepada masyarakat adat Enggano.

\section{Opsi Hukum Pengakuan Hak Adat}

Berdasarkan identifikasi prasyarat pengakuan hak adat dan desa adat seperti yang telah dijelaskan di atas, opsi hukum yang dapat ditempuh oleh masyarakat Enggano dalam memperjuangkan hak ulayat mereka mulai dari tingkatan terendah hingga tertinggi, adalah sebagai berikut.

\section{Peraturan Desa}

Peraturan desa merupakan peraturan terendah yang bisa ditempuh dalam hal instrumen formal pengakuan adat wilayah dan hak ulayat Enggano. Peraturan desa memang tidak memiliki legitimasi yang kuat, terutama jika tidak dikuatkan oleh peraturan yang lebih tinggi di atasnya, seperti peraturan bupati dan peraturan gubernur. Lingkup peraturan desa hanya mengatur adat atau hak ulayat per desa. Hal ini sulit untuk diterapkan dalam hal masyarakat Enggano yang terdiri dari lima suku asli dan tinggal pada enam desa. Jika peraturan 
itu diberlakukan, hanya akan terdapat lima peraturan desa dan satu desa pendatang, yaitu Kaamay, tidak akan memiliki hak ulayat.

\section{Peraturan Daerah.}

Ada berbagai tingkatan peraturan daerah (perda) yang bisa dipakai untuk mengukuhkan hak adat, antara lain perda provinsi, perda kabupaten/kota, peraturan gubernur, seerta peraturan bupati/walikota. Perda merupakan sumber kekuatan hukum yang efektif bagi pengakuan masyarakat hukum adat. Peraturan pada level ini diamanatkan di berbagai peraturan perundangan seperti yang telah disebutkan di atas. Salah satu contohnya adalah UU Kehutanan No. 41/1999 yang menyatakan bahwa pengakuan masyarakat adat dilakukan dengan peraturan daerah. Permendagri menetapkan format jenis perda yang bisa digunakan untuk kepentingan ini adalah Keputusan Kepala Daerah Bupati/ Walikota.

\section{Desa Adat}

Desa adat merupakan opsi yang juga bisa dipakai untuk mendukung pengakuan hak ulayat dan adat masyarakat Enggano. Selama ini, masalah yang terjadi di Enggano terutama terkait masalah tanah dan pengelolaan sumber daya alam. Hal itu bersumber dari adanya dualisme kepemimpinan antara pemerintahan desa dan kecamatan di satu sisi dan lembaga adat di sisi lain. Para kepala adat beranggapan bahwa telah terjadi eksploitasi sumber daya alam di Enggano yang akan mengancam kelestarian sumber daya dan pulau Enggano sendiri. Untuk itu, para kepala adat menginginkan untuk dilibatkan lebih jauh dalam pengelolaan dan manajemen pembangunan di Enggano. Pemilihan opsi desa adat bisa mengatasi masalah ini.

Desa adat adalah kesatuan masyarakat hukum yang memiliki batas wilayah yang berwenang untuk mengatur dan mengurus urusan pemerintahan dan kepentingan masyarakat setempat berdasarkan prakarsa masyarakat, hak asal usul, dan/atau hak tradisional yang diakui dan dihormati dalam sistem pemerintahan Negara Kesatuan Republik Indonesia. Pemerintahan desa adat menyelenggarakan fungsi permusyawaratan dan musyawarah desa adat sesuai dengan susunan asli desa adat atau dibentuk baru sesuai dengan prakarsa masyarakat desa adat. Susunan kelembagaan, pengisian jabatan, dan masa jabatan kepala desa adat berdasarkan hukum adat ditetapkan dalam peraturan daerah provinsi.

Namun demikian, hal pertama yang harus diperhatikan adalah apakah keseluruhan elemen masyarakat mendukung opsi ini karena salah satu kunci kesuksesan opsi ini adalah dukungan dan komitmen dari masyarakat secara keseluruhan. Tantangan dalam membuat komitmen atas pilihan ini adalah heterogeninas masyarakat itu sendiri. Seperti sudah di singgung pada bagian sebelumnya, Orang Enggano terdiri dari campuran berbagai suku, termasuk suku pendatang yang diintegrasikan ke dalam dengan sebutan Suku Kaamay. Untuk mengatasi hal tersebut, lembaga adat, pemerintahan desa, pemerintahan kabupaten dan provinsi harus duduk bersama untuk merencanakan masa depan Enggano.

\section{Kesimpulan}

Masyarakat Enggano memiliki adat istiadat yang kuat yang masih dijadikan rujukan oleh sebagian besar anggota masyarakat. Masyarakat hidup berdasarkan hubungan kekeluargaan dengan sistem garis asal keturunan yang dinamakan suku. Penduduk asli Enggano terdiri dari lima suku asli dan satu suku pendatang, yaitu Suku Kauno, Suku Kahahowa, Suku Kaharuba, Suku Kaitora, Suku Kaarubi, dan satu suku pendatang-Suku Kaamay. Struktur masyarakat adat terdiri dari Pabuki sebagai pemimpin tertinggi dari lembaga adat di Enggano yang mengepalai kepala suku dan kepala suku pintu.

Aturan-aturan pemerintah mengakui adanya hak ulayat adat dengan UU Pengelolaan Agraria (UUPA) dan UU No. 41/1999 tentang Kehutanan, UU No. 27/2007 Tentang Pengelolaan Pesisir dan Pulau-Pulau Kecil, UU No. 39 Tahun 2014 tentang Perkebunan, Permendagri No. 52 Tahun 2014 tentang Pedoman Pengakuan dan Perlindungan Masyarakat Hukum Adat, serta Peraturan Menteri Agraria No. 5/1999 tentang Pedoman Penyelesaian Masalah Hak Ulayat Masyarakat Adat yang dicabut dengan Peraturan Menteri Agraria dan Tata Ruang No. 9/2015 tentang Tata Cara Penetapan Hak Komunal Atas Tanah Masyarakat Hukum Adat dan Masyarakat yang Berada dalam Kawasan Tertentu.

Sebenarnya peraturan tentang pengakuan adat sudah lengkap, seperti diatur dalam Permendagri No. 52/2014 tentang Pengakuan Masyarakat Hukum Adat serta Prosedur 
Pengakuan Tanah Ulayat yang diatur dalam Peraturan Menteri Agraria dan Tata Ruang No. 9/2015. Bahkan, sekarang, melalui UU Desa, dimungkinkan adanya pembentukan desa adat. Permasalahannya sekarang adalah bagaimana pemerintah daerah melindungi hak-hak adat masyarakat adatnya karena mandat yang diberikan oleh UU menyebutkan bahwa hak adat diakui jika telah ditetapkan dalam peraturan daerah. Selama belum ada peraturan daerah yang mengakui masyarakat adat, maka masyarakat adat belum diakui secara hukum.

Masyarakat Enggano dapat dikatakan memiliki elemen-elemen dasar yang memenuhi syarat untuk diakui hak adatnya oleh pemerintah, bahkan memenuhi syarat untuk pembentukan desa adat. Hal yang diperlukan saat ini adalah, Pertama, membangun komitmen bersama di antara elemen-elemen masyarakat Enggano akan pilihan dan rencana mereka mengatur hidupnya ke depan. Hal yang paling penting dalam konteks ini adalah menyelesaikan konflikkonflik yang ada di masyarakat terkait dengan penguasaan tanah, kesepakatan tentang wilayah ulayat, dan aturan-aturan pengelolaan sumber daya alam yang ada di dalamnya.

Kedua, dukungan Pemerintah Daerah Kabupaten Bengkulu Utara dan Provinsi Bengkulu dalam menindaklanjuti keinginan masyarakat adat di Enggano. Hal itu bisa dilakukan dengan cara (a) Identifikasi Masyarakat Hukum Adat; (b) Verifikasi dan validasi Masyarakat Hukum Adat; dan (c) Penetapan Masyarakat Hukum Adat. Bupati/ Walikota melalui camat atau sebutan lain melakukan identifikasi dengan melibatkan masyarakat hukum adat atau kelompok masyarakat. Lalu bupati/walikota melakukan penetapan pengakuan dan perlindungan masyarakat hukum adat berdasarkan rekomendasi Panitia Masyarakat Hukum Adat dengan Keputusan Kepala Daerah. Pada Umumnya pengakuan dan penetapan masyarakat hukum adat dilakukan melalui perda. Pemerintah Daerah bisa memprakarsai pembentukan perda pengakuan masyarakat adat Enggano dan wilayah adat Enggano yang nantinya disampaikan kepada DPRD untuk dirapatkan dan disahkan sebagai Perda Pengakuan Masyarakat Adat Enggano.

Pengakuan Adat Enggano masih memerlukan perjalanan yang panjang. Akan tetapi, kemungkinan terwujudnya pengakuan tersebut bukanlah hal yang mustahil. Hal ini telah ditandai oleh adanya dorongan dari masyarakat sendiri, meskipun belum "bulat", dan dukungan dari Pemerintah serta Dewan Perwakilan Daerah (DPRD) Kabupaten Bengkulu Utara. Jika tidak segera diakui dan dilindungi, dikhawatirkan tidak ada lagi masyarakat adat Enggano yang saat ini sudah semakin terkikis oleh budaya luar dan juga penjualan tanah adat kepada para pendatang. Dukungan Pemerintah Daerah Bengkulu terhadap masyarakat adat Enggano dengan pengakuan dan perlindungan adat dalam perda juga sangat diperlukan dalam upaya melestarikan pulau Enggano yang semakin terancam akibat eksploitasi sumber daya alam. Namun demikian, prinsip kehatihatian harus tetap digunakan. Usaha-usaha pengakuan hak adat ini harus dilakukan dengan perhitungan yang matang, kesepakatan yang bulat, serta mengutamakan prinsip-prinsip keadilan, untuk menghindari lahirnya efek-efek negatif di masa yang akan datang.

\section{Daftar Pustaka}

Hartiman, Andry Harijanto. (2015). Antropologi Hukum: Studi Kasus di Bengkulu. Selat Malaka Copy Centre Press.

Keputusan Bupati Bengkulu Utara No. 175 Tahun 2014 tentang Pencadangan Kawasan Konservasi Perairan Derah Enggano Kabupaten Bengkulu Utara.

Kementrian Perencanaan Pembangunan Nasional Bappenas. (2004). Pengembangan Pulau Enggano sebagai Pusat Industri Berbasis Maritim dan Pariwisata di Provinsi Bengkulu.

Lembaga Adat Enggano. (2007). Himpunan Hukum Adat Istiadat dan Seni Budaya Asli-Pulau Enggano. Tidak diterbitkan.

Lembaga Adat Enggano. (2009). Himpunan Hukum Adat Istidat dan Seni Budaya. Tidak diterbitkan.

Majalah Berita Mingguan GATRA, "Perkara Melijo Di Enggano", 2 September 1995.

Safiri, Myrna. (2015). "Pengakuan dan Perlindungan Masyarakat Hukum Adat dan Wilayah Adat: Peluang dan tantangan dalam kerangka hukum nasional dan daerah". Presentasi dalam Seminar Pengakuam Masyarakat Adat dalam Sistem Ketatanegaraan di Indonesia: Studi Kasus pada Pengakuan Masyarakat 
Hukum Adat Marga Suku IX, Bengkulu, 19 November 2015.

Safitri, Myrna A dan Luluk Uliyah. (2014). Adat di Tangan Pemerintah Daerah: Panduan Penyusunan Produk Hukum Daerah untuk Pengakuan dan Perlindungan Hak Masyarakat Hukum Adat. Jakarta: Episma Institute.

\section{Website}

Firmasyah Tasril, Mengamati Masyarakat Adat Enggano Membuat Perda. 5/1/2014 <http://www.kompasiana.com/sudutruan $\mathrm{g} /$ mengamati-semangat-masyarakatadat-enggano-membuat-perda_54f916 40a33311f9028b470c>

BP REDD ${ }^{+}$, Masyarakat Adat, http://www. reddplus.go.id/kegiatan/kegiatanmasyarakat-adat

Walhi. (2014). Briefing Paper Dampak Politik Rejim Korporasi Terhadap Sumber Daya Pesisir dan Pulau-Pulau Kecil di Indonesia Ditengah Situasi Perubahan Iklim dan Krisis Pangan Nasional. < http://www.walhi.or.id/wp-content/ uploads/2014/06/Briefing-PaperHARLING-2014_Walhi.pdf>

\section{Wawancara}

Wawancara dengan Paabuki

Wawancara dengan Kepala Adat

Wawancara dengan Pak Camat dan Kepala Desa

\section{Perundang-Undangan}

UU Pengelolaan Agraria (UUPA) No. 5/1960

UU No. 41/1999 tentang Kehutanan

UU No. 27/2007 tentang Pengelolaan Pesisir dan Pulau-Pulau Kecil

UU No. 39/2014 tentang Perkebunan

UU No. 6/2014 tentang Desa

Peraturan Menteri Agraria No. 5/1999 tentang Pedoman Penyelesaian Masalah Hak Ulayat Masyarakat Adat yang dicabut dengan Peraturan Menteri Agraria dan Tata Ruang No. 9 tahun 2015 tentang Tata Cara Penetapan Hak Komunal Atas Tanah Masyarakat Hukum Adat dan Masyarakat yang Berada Dalam Kawasan Tertentu.

Permendagri No. 52 Tahun 2014 tentang Pedoman Pengakuan dan Perlindungan Masyarakat Hukum Adat, Permen LHK No. P.32/Menlhk Setjen/2015 tentang Hutan Hak.

Peraturan Bersama Menteri Dalam Negeri Republik Indonesia, Menteri Kehutanan Republik Indonesia, Menteri Pekerjaan Umum Republik Indonesia, Dan Kepala Badan Pertanahan Nasional Republik Indonesia No. 79 Tahun 2014, No. Pb.3/Menhut-11/2014, No. 17/Prt/M/2014, dan No. 8/Skb/X/2014 Tentang Tata Cara Penyelesaian Penguasaan Tanah yang Berada dalam Kawasan Hutan. 